\title{
Kajian Pengembangan dan Pemanfaatan Tanaman Pakan Leguminosa Mendukung Peningkatan Produksi Ternak Sapi di Nusa Tenggara Timur
}

\section{(The Assessment of Forage Legumes Development and Usage in Supporting the Improvement Cattle Production in East Nusa Tenggara)}

\author{
Kana Hau D, Nulik J \\ Balai Pengkajian Teknologi Pertanian Nusa Tenggara Timur \\ Jl. Timor Raya km 32, Naibonat, Kupang, Nusa Tenggara Timur \\ debora_nulik@yahoo.com
}

\begin{abstract}
Legumes have various usages, among other things in improving soil fertility, and as an important source of livestock feed (forage). As livestock feed, legumes have high quality, and available anytime, thus their development as feed is urgently needed. The aim of this research is to observe the adopting of using legume tree to support the increasing of cattle productivity in East Nusa Tenggara (NTT) Province. Their assessments in developement and usage in NTT have been conducted at farmer's level between 2006 to 2017 for herbaceous legumes, and from 2012 to 2016 for tree legume species Leucaena leucocephala cv Tarramba, involving various stakeholders. The following paper reviewed on the previous important published findings and various current results of the development and use of the legumes in NTT recorded through an on farm record keeping method, elaborated and descriptivelly discussed.
\end{abstract}

Key Words: Herbaceous Legumes, Leucaena leucocephala cv Tarramba, Development, Usage, East Nusa Tenggara

\begin{abstract}
ABSTRAK
Leguminosa mempunyai berbagai macam manfaat, diantaranya untuk menyuburkan tanah dan sumber pakan ternak. Sebagai pakan ternak leguminosa mempunyai kualitas tinggi dan tersedia sepanjang tahun. Oleh karena itu, pengembangannya sebagai tanaman pakan sangat diperlukan. Tujuan penulisan ini adalah untuk melihat perkembangan pemanfaatan tanaman leguminosa untuk meningkatkan produktivitas sapi di Provinsi Nusa Tenggara Timur. Kajian pengembangan dan pemanfaatan tanaman pakan leguminosa di Nusa Tenggara Timur telah dilakukan di tingkat petani dari tahun 2006-2017 bagi leguminosa herba dan dari tahun 2012-2016 bagi leguminosa pohon Leucaena leucocephala cv Tarramba, dengan melibatkan berbagai stakeholder. Tulisan ini mereview berbagai capaian penting yang telah dipublikasikan dan yang masih dicatat saat ini dengan cara on farm record keeping, dijelaskan dan dibahas secara deskriptif.
\end{abstract}

Kata Kunci: Leguminosa Herba, Leucaena leucocephala cv Tarramba, Pengembangan, Pemanfaatan, Nusa Tenggara Timur

\section{PENDAHULUAN}

Nusa Tenggara Timur (NTT) sebagai salah satu daerah penting sentra produksi ternak sapi sudah lama dikenal dengan baik, namun sebagian besar peternaknya masih memelihara ternak sapi secara ekstensif tradisional, yaitu dengan membiarkan ternaknya mencari makan sendiri di padang rumput alam, yang pertumbuhan dan produksinya berfluktuasi mengikuti musim (Nulik \& Bamualim 1998). Hal ini dipersulit lagi dengan rendahnya kualitas hijauan (3-8\% protein) yang dapat diperoleh ternak di padang rumput (Nulik \& Kana Hau 2016), bahkan selama musim hujan ketika hijauan rumput alam masih 
dalam tahap pertumbuhan vegetatif (hanya mencapai $10 \%$ kandungan protein kasar). Walaupun di dalam komposisi hijauan padang rumput alam terdapat cukup beraneka ragam jenis hijauan leguminosa herba lokal (Aeschynomene sp, Alysicarpus spp, Macroptilium triloba, M. atropurpureum dan Censtrosema pubescens), namun persentasenya dalam komposisi sangat kecil (<5\%) (Kana Hau 2014), sehingga kualitas pakan secara keseluruhan masih rendah. Karena itu perlu melakukan kajian pengembangan dan pemanfaatan tanaman pakan leguminosa yang sesuai dengan kondisi agroklimat yang spesifik lokasi, dengan kondisi kemarau yang panjang guna meningkatkan kualitas pakan ternak, menunjang produktivitas yang tinggi dan berkelanjutan. Dalam upaya pengembangan hijauan makanan ternak berbasis leguminosa, yaitu leguminosa pohon (Leucaena leucoephala cv Tarramba) dan leguminosa herba (Clitoria ternatea cv Milgarra) di NTT di pandang sangat penting untuk memperhatikan faktor-faktor penghambat dan pendukung, seperti yang telah dilakukan penelitiannya pada awal introduksi teknologi (Kana Hau et al. 2014), yang selanjutnya selama masa-masa pengembangan faktor-faktor ini makin diperkaya untuk menjadi perhatian dalam kegiatan pengembangan dan pemanfaatan pakan leguminosa lebih lanjut ke depan. Tujuan penulisan ini adalah untuk melihat perkembangan pemanfaatan leguminosa pohon untuk meningkatkan produktivitas sapi di Provinsi NTT.

\section{MATERI DAN METODE}

Data diperoleh dari hasil-hasil penelitian dan pengkajian selama tahun 2006 sampai dengan 2017 yang secara cermat mengkaji aspek-aspek yang berkaitan dan berpengaruh dalam upaya pengembangan dan pemanfaatan hijauan pakan berkualitas berbasis leguminosa, di beberapa lokasi di NTT. Pencatatan data diperoleh dari berbagai lokasi, baik kelompok tani yang sudah berhasil, petani perorangan, kelompok tani, LSM dan stakeholder lainnya yang baru dan sedang melakukan upaya pengembangan dan pemanfaatan pakan leguminosa. Pada tingkat petani diterapkan metode on farm record keeping (OFRK) antara lain mencatat data dan informasi seperti luas areal tanam, jumlah tanaman yang ditanam setiap tahun hingga awal 2017 (khusus untuk jenis lamtoro), keuntungan-keuntungan yang sudah dirasakan dari aktivitas pemanfaatan hijauan pakan, faktor-faktor yang menghambat dan menunjang adopsi teknologi. Pencatatan juga dilakukan pada kurang lebih 21 kelompok pengembangan (fase penelitian kedua, mulai tahun 2014-2017) dengan komunikasi lebih banyak dilakukan melalui telepon seluler dengan petani, kelompok tani dan penyuluh pertanian lapang yang bertugas di wilayah kerja dan terlibat dalam kegiatan kajian pengembangan budidaya dan pemanfaatan leguminosa sebagai pakan dan dalam sistem usaha tani. Fokus lokasi kegiatan yang dikunjungi secara rutin disajikan pada Tabel 1. Informasi dan data yang diperoleh kemudian ditampilkan secara deskriptif.

Tabel 1. Lokasi dan karakteristik kelompok tani penelitian dan pengkajian

\begin{tabular}{|c|c|c|}
\hline Lokasi & $\begin{array}{l}\text { Kelompok tani, jumlah anggota, luas areal } \\
\text { penanaman, jenis tanah, jumlah dan jenis tanaman }\end{array}$ & Keterlibatan dan aktivitas \\
\hline $\begin{array}{l}\text { Desa Kuanheun } \\
\text { Kec. Kupang Barat } \\
\text { Kab. Kupang }\end{array}$ & $\begin{array}{l}\text { Kelompok Bersaudara dan Oematnunu, } 50 \text { anggota, } \\
\text { luasan } 10 \text { ha, jenis tanah merah alfisol, } 50.000 \text { pohon } \\
\text { lamtoro Tarramba }\end{array}$ & $\begin{array}{l}\text { Tahun kegiatan 2012-2017 } \\
\text { Aktivitas perbenihan }\end{array}$ \\
\hline $\begin{array}{l}\text { Desa Ponain } \\
\text { Kec. Amarasi } \\
\text { Kab. Kupang }\end{array}$ & $\begin{array}{l}\text { Baru terbentuk } 30 \text { anggota, luasan } 15 \text { ha, tanah } \\
\text { dominan alfisol dan sedikit vertisol, } 75.000 \text { pohon } \\
\text { lamtoro Tarramba }\end{array}$ & $\begin{array}{l}\text { Tahun 2012-2017 kajian } \\
\text { penggemukan ternak sapi } \\
\text { berbasis lamtoro lokal dan } \\
\text { Tarramba serta perbenihan }\end{array}$ \\
\hline
\end{tabular}




\begin{tabular}{|c|c|c|}
\hline Lokasi & $\begin{array}{l}\text { Kelompok tani, jumlah anggota, luas areal } \\
\text { penanaman, jenis tanah, jumlah dan jenis tanaman }\end{array}$ & Keterlibatan dan aktivitas \\
\hline $\begin{array}{l}\text { Desa Oebola Dalam } \\
\text { Kec. Kupang Timur } \\
\text { Kab. Kupang }\end{array}$ & $\begin{array}{l}\text { Kelompok Bersaudara, anggota } 25 \text { orang, luasan } 25- \\
30 \text { ha, jenis tanah alfisol dan inseptisol berkarang, } \\
\text { lamtoro Tarramba } 125.000-150.000 \text { pohon }\end{array}$ & $\begin{array}{l}\text { Mulai terlibat sejak tahun } \\
\text { 2012. Aktivitas } \\
\text { penggemukan ternak dan } \\
\text { perbenihan }\end{array}$ \\
\hline $\begin{array}{l}\text { Desa Campong } 1 \\
\text { Kec. Fatuleu } \\
\text { Kab. Kupang }\end{array}$ & $\begin{array}{l}\text { Kelompok Setetes Madu, Talekomonit, Tunas Baru } \\
\text { dan Sabubani, } 120 \text { anggota, luasan }>150 \text { ha, jenis } \\
\text { tanah vertisol, inseptisol dan molisol, } \\
\text { jumlah } 240.000 \text { pohon }\end{array}$ & $\begin{array}{l}\text { Keterlibatan sejak tahun } \\
\text { 2014, dengan kegiatan } \\
\text { produksi benih dan } \\
\text { penggemukan ternak sapi }\end{array}$ \\
\hline $\begin{array}{l}\text { Desa Uel } \\
\text { Kec. Kupang Timur } \\
\text { Kab. Kupang }\end{array}$ & $\begin{array}{l}\text { Kelompok Mira Muri, } 20 \text { anggota, luasan } 10 \text { ha, jenis } \\
\text { tanah vertisol, menanam Tarramba dan } \\
\text { Clitoria ternatea }\end{array}$ & $\begin{array}{l}\text { Terlibat sejak tahun } 2014 \text {, } \\
\text { produksi benih dan } \\
\text { penggemukan ternak } \\
\text { berbasis leguminosa }\end{array}$ \\
\hline $\begin{array}{l}\text { Desa Kambata Tana } \\
\text { Kec. Pandawai } \\
\text { Kab. Sumba Timur }\end{array}$ & $\begin{array}{l}\text { Perorangan (dua petani), jenis tanah kapur marjinal } \\
\text { dan tepian sawah (tanah vertisol), luasan } 2 \text { ha, } \\
\text { menanam Tarramba } 5.000 \text { pohon }\end{array}$ & $\begin{array}{l}\text { Keterlibatan sejak tahun } \\
\text { 2012, sebagian besar } \\
\text { tanaman gagal tumbuh }\end{array}$ \\
\hline $\begin{array}{l}\text { Desa Laindeha } \\
\text { Kec. Pandawai } \\
\text { Kab. Sumba Timur }\end{array}$ & $\begin{array}{l}\text { Kelompok Laindeha, } 20 \text { anggota, tanah campuran } \\
\text { alfisol dan inseptisol, menanam } 5.000 \text { pohon } \\
\text { Tarramba }\end{array}$ & $\begin{array}{l}\text { Pertumbuhan agak lambat, } \\
\text { karena kebakaran yang } \\
\text { sering setiap tahun }\end{array}$ \\
\hline $\begin{array}{l}\text { Desa Wanga } \\
\text { Kec. Umalulu } \\
\text { Kab. Sumba Timur }\end{array}$ & $\begin{array}{l}\text { Kelompok Maju Bersama, } 20 \text { anggota, luasan } 2 \text { ha, } \\
\text { jenis tanah vertisol berpasir, menanam } 5.000 \text { pohon } \\
\text { Tarramba }\end{array}$ & $\begin{array}{l}\text { Terlibat sejak 2012, } \\
\text { memanfaatkan Tarramba } \\
\text { dan Lamtoro lokal untuk } \\
\text { penggemukan ternak }\end{array}$ \\
\hline $\begin{array}{l}\text { Desa Melolo } \\
\text { Kec. Umalulu } \\
\text { Kab. Sumba Timur }\end{array}$ & $\begin{array}{l}\text { Perorangan (satu kepala keluarga petani), jenis tanah } \\
\text { alfisol, menanam Clitoria ternatea }\end{array}$ & $\begin{array}{l}\text { Sebagai pakan suplemen } \\
\text { bagi ternak gembala (induk, } \\
\text { pejantan dan anak) sapi } \\
\text { Sumba Ongole }\end{array}$ \\
\hline $\begin{array}{l}\text { Desa Paraipuluhamu } \\
\text { Kec. Umalulu } \\
\text { Kab. Sumba Timur }\end{array}$ & $\begin{array}{l}\text { Komunitas Gereja Bebas, } 10 \text { anggota, Jenis tanah } \\
\text { vertisol berpasir dan alfisol, menanam Clitoria } \\
\text { ternatea seluas } 4 \text { ha }\end{array}$ & $\begin{array}{l}\text { Sebagai pakan suplemen } \\
\text { ternak gembala, mulai } \\
\text { terlibat tahun } 2016\end{array}$ \\
\hline
\end{tabular}

\section{HASIL DAN PEMBAHASAN}

\section{Faktor pendukung}

Faktor-faktor pendukung upaya pengembangan tekonologi pemberian pakan berbasis leguminosa, terutama dari jenis Leucaena leucocephala cv Tarramba, diantaranya:

\section{Faktor metode diseminasi}

Adanya kunjungan dan diskusi di kelompok yang sudah berhasil sebelumnya. Pada kasus petani di Kelompok Setetes Madu di Desa Campong 1 adalah dengan melihat keberhasilan pada Kelompok Tani Bersaudara di Desa Oebola Dalam (merupakan desa tetangga). Sedangkan kelompok Bersaudara Desa Oebola Dalam termotivasi oleh keberhasilan petani perorangan di Desa Ponain, Kecamatan Amarasi dengan cara mengunjungi dan berdiskusi ketika ada kunjungan silang cross visit. Adanya pendampingan yang konsisten oleh petugas teknis dari dinas peternakan kabupaten, terutama setelah petani mengetahui dengan baik keunggulan jenis tanaman pakan Leucaena leucocephala $\mathrm{cv}$ Tarramba, yaitu dalam hal daya tahannya terhadap kemarau 
panjang, daya toleransi yang tinggi terhadap serangan hama kutu loncat dan daya tahan yang tinggi terhadap pemangkasan berulang, serta kemampuan memproduksi hijauan berkualitas dalam jangka waktu yang panjang ( $>50$ tahun) setelah pemangkasan pertama (setelah mencapai umur 10 bulan hingga satu tahun). Pemasukan kultivar lamtoro toleran kutu loncat, khususnya untuk NTT merupakan pendukung utama, mengingat provinsi ini merupakan provinsi yang awalnya sangat bergantung kepada penggunaan lamtoro. Namun pernah mengalami serangan berat hama pada kultivar-kultivar yang digunakan sebelumnya sehingga pengembangan ke berbagai lokasi lain dari lokasi inti di Amarasi menjadi relatif terhenti sama sekali. Baru bangkit kembali semangat untuk mengembangkan lamtoro sebagai pakan utama setelah masuknya kultivar Tarramba yang sudah diamati lebih unggul dari kultivar-kultivar sebelumnya (Nulik et al. 2004).

\section{Faktor keunggulan leguminosa}

Pada leguminosa herba petani menjadi tertarik dalam beberapa hal, antara lain: (1) Hijauan pakan ini mampu meningkatkan kesuburan lahan setelah penanaman leguminosa herba, misalnya hasil padi yang lebih baik (10-15\%) walau jumlah pupuk berkurang $(50 \%)$ setelah tanaman leguminosa herba; (2) Petani mendapatkan tambahan pendapatan dari menjual benih; (3) Dapat ditanam bersama dengan tanaman pangan jagung dan padi secara relay atau berotasi setelah tanaman jagung atau padi, sementara lamtoro hanya bisa ditanam secara monokultur, sebagai tanaman pembentuk lorong atau ditanam di batas-batas lahan sebagai pagar hidup; (4) Menyediakan pakan berkualitas selama musim hujan dan awal kemarau yang dipanen segar; (5) Mampu memperbaiki kondisi skor tubuh induk produktif selama kemarau dan meningkatkan performans reproduksi (pada ternak sapi Sumba Ongole (SO), di Desa Melolo dan Praipulhamu, Kabupaten Sumba Timur).

Keuntungan yang dapat diperoleh dari tanaman pakan lamtoro Tarramba: (1) Menghasilkan hijauan berkualitas sepanjang tahun sehingga mengurangi waktu petani untuk mencari pakan di padang atau di hutan; (2) Petani bisa beternak secara intensif sehingga kotoran ternak tersedia dalam jumlah yang cukup banyak didekat pemukiman sehingga dapat dimanfaatkan untuk mengasilkan energi terbarukan berupa biogas untuk keperluan memasak (kompor gas) dan penerangan bagi lokasi yang belum dijangkau listrik PLN, misalnya di Desa Oebola Dalam; (3) Memberikan tambahan pandapatan tunai dari penjualan pakan ke pasar hewan selama kemarau. Sebelumnya tidak pernah diperoleh pendapatan dari lahan kering karena kurang produktif dan menjual benih dengan harga per kilogram antara Rp. 40.000-50.000; (4) Meningkatkan daya guna lahan yang relatif kurang produktif untuk tanaman pangan (jagung) karena berbatu-batu serta menekan perkembangan tanaman gulma Chromolaena odorata yang sebelumnya mendominasi lahan padang penggembalaan dan menekan produksi rumput alam bagi ternak gembala (kasus Kelompok Tani Setetes Madu); (5) Pakan daun lamtoro segar dapat diperoleh sepanjang tahun dengan pemangkasan yang teratur dan dampaknya pakan sepanjang tahun selalu tersedia dan pertumbuhan ternak yang dipelihara secara intensif di kandang mempunyai performans yang jauh lebih baik (berat pasar $250 \mathrm{~kg}$ dicapai di bawah umur dua tahun) dibandingkan dengan sebelumnya (ternak mencapai berat pasar $250 \mathrm{~kg}$ pada umur 4-5 tahun) ketika petani hanya berharap dari padang penggembalaan dengan melepaskan ternak mencari makan sendiri (gembala bebas di padang rumput alam), pada ternak jantan sapi Bali di Timor.

Adopsi budidaya lamtoro Tarramba yang saat ini nampak lebih cepat berkembang antara lain dipicu oleh mudahnya pengelolaan tanaman ini dalam sistem usahatani lahan kering dan sebelumnya sudah menjadi bagian dalam sistem, terutama di kawasan Amarasi. 
Juga adopsi oleh petani di Desa Oebola Dalam yang dapat menjual hijauan segar ke pasar hewan terdekat telah memotivasi pengembangan lebih jauh. Akses ke pasar ternak merupakan salah satu faktor menentukan dalam adopsi pakan unggul (Bassa 2016).

Diseminasi dengan cara petani ke petani (farmer to farmer) merupakan salah satu cara efektif dalam upaya perluasan pengembangan budidaya dan pemanfaatan leguminosa pohon (Wambugu et al. 2011).

\section{Faktor penghambat}

Hambatan-hambatan dalam upaya pengembangan dan pemanfaatan hijauan pakan berbasis leguminosa (selain hambatan bagi pengembangan lamtoro Tarramba yang telah diamati oleh Kana Hau et al. (2014) antara lain meliputi:

\section{Faktor kepemilikan ternak sapi}

Lebih sulit untuk mengajak petani yang tidak memiliki ternak sapi sendiri untuk melakukan penanaman dan pengembangan hijauan pakan leguminosa, terutama sebelum mereka dapat melihat dan merasakan manfaatnya. Misalnya petani di Desa Oebola Dalam yang ikut partisipasi pada penelitian dan pengkajian penanaman dan pemanfaatan lamtoro Tarramba sangat berkeberatan menanam tanaman ini karena tidak memiliki ternak sapi dan berpendapat bahwa tanaman ini bukan pangan, namun karena kesepakatan kelompok petani yang bersangkutan ikut juga melakukan penanaman dan setelah tanaman mulai berproduksi dan petani bisa menjual hijauan ke pasar hewan, dengan sendirinya petani terus menambah jumlah tanaman dan luasan areal pertanaman.

\section{Faktor palatabilitas dan kebiasaan gembala bebas}

Di Sumba Timur dengan padang penggembalaan yang luas dan ternak yang digembalakan bebas menjadikan petani enggan untuk melakukan penanaman lamtoro, terutama juga karena ternak sapi SO sulit sekali untuk dibiasakan mengonsumsi pakan ini, bahkan sebagian ternak lebih memilih makan jerami atau rumput kering dibandingkan dengan hijauan lamtoro yang tumbuh alamiah di tempat yang sama selama musim kemarau.

\section{Faktor pengetahuan petani}

Kurang pahamnya petani dengan cara-cara pemberian pakan yang tepat untuk mempercepat pertumbuhan dan pertambahan berat badan ternak, mengakibatkan pemberian pakan dilakukan sekedarnya saja dan berdampak pada lamanya pemeliharaan ternak sampai mencapai berat pasar (250 kg untuk sapi Bali dan $350 \mathrm{~kg}$ untuk sapi SO). Kurangnya pengetahuan (misalnya, tentang keberadaan pakan sesuai dengan lokasi setempat dan tentang implementasinya serta pengelolaannya), merupakan salah satu faktor penghambat dalam adopsi budidaya pakan ternak unggul.

\section{Model pengembangan}

Dalam upaya pengembangan dan pemanfaatan hijauan tanaman pakan ternak leguminosa (pohon dan herba) petani mengadopsi dan menyesuaikan dengan kondisi usaha taninya (luas lahan, kesuburan lahan, tanaman pangan yang diusahakan, kemampuan modal dan tenaga keluarga atau kemampuan kerja gotong royong kelompok) sehingga model yang dikembangkan bisa sama atau berbeda beda dari petani ke petani lainnya. 


\section{Leguminosa pohon}

Sistem penanaman leguminosa pohon yang diterapkan adalah model lorong, model monokultur dan pagar hidup, sedangkan model sebelumnya adalah model sistem amarasi. Pada sistem usaha tani lahan kering, lamtoro tidak ditanam bersama dengan tanaman pangan secara bercampur ataupun menggunakan jarak tanam yang dekat karena akan memberi naungan yang berat pada tanaman pangan yang ditanam bersama, misalnya jagung dan akan mengurangi produksi tanaman pangannya akibat kompetisi antara tanaman lamtoro dan tanaman pangan. Sistem amarasi menggunakan cara tebas bakar dan berpindah, yaitu kebun atau hutan lamtoro pada waktu persiapan lahan (bulan September hingga November) dengan cara menebas semua tegakan lamtoro yang ada dalam lahan yang akan ditanami jagung dan kemudian dibakar dan penanaman jagung dilakukan pada awal musim hujan ketika curah hujan mulai stabil. Setelah panen jagung, tanaman lamtoro yang bertumbuh kembali akan diperlakukan sama lagi pada tahun berikutnya. Pengusahaan lahan lamtoro ini akan dilakukan beberapa tahun sampai kebanyakan lamtoro sudah mati dan tidak tumbuh lagi dan kesuburan lahan mulai menurun dan dihutankan lagi dengan cara menyebar benih lamtoro ke dalam lahan tersebut.

Model tanaman lorong juga bisa dilakukan secara tebas bakar, namun yang sering dilakukan selama penelitian dan pengkajian oleh petani adalah dengan menggunakan jarak antar tanaman pembentuk lorong (hedge row) dengan jarak besar (4-6 m antar barisan tanaman) dan tidak dilakukan penebasan rata dengan permukaan pada tanaman lamtoro, tetapi hanya dipangkas seperlunya untuk dimanfaatkan sebagai pakan ternak atau pupuk hijau.

\section{Leguminosa herba}

Penanaman leguminosa herba dilakukan monokultur secara berotasi dengan tanaman pangan (jagung dan padi). Sitem ini dilakukan oleh beberapa petani yang mengusahakan sawah tadah hujan, dimana setelah panen padi (bulan Mei-Juni) kemudian leguminosa herba ditanam, dengan menggunakan bantuan penyiraman dari air sumur bor dan pakan yang dihasilkan dimanfaatkan dalam bentuk segar atau dikeringkan sebagai hay yang diberikan kepada ternak sapi sebagai pakan suplemen bagi ternak yang dikandangkan atau digembalakan (Nulik \& Kana Hau 2016). Menurut petani yang melakukan cara ini penampilan tanaman padi setelah leguminosa herba (dengan menggunakan pemupukan urea separuh dari tahun sebelumnya) jauh lebih baik dibandingkan dengan padi tahun sebelumnya (Abi et al. 2016). Hasil penelitian menggunakan beberapa jenis tanaman leguminosa herba, memberikan hasil yang nyata lebih baik jika tanaman leguminosa yang ditanam tidak dipangkas dan diangkut biomasanya dari plot dibandingkan dengan yang dipangkas dan diangkut semua biomasanya (Hosang et al. 2016).

Penanaman dengan cara relay (tumpang sari) yaitu penanaman yang dilakukan bersamaan dengan penanaman jagung, ketika tanaman jagung mencapai umur dan tinggi tanaman tertentu (setinggi lutut orang dewasa), atau ketika jagung telah mencapai masa pembungaan (Nulik et al. 2013).

\section{Model pemanfaatan}

\section{Sebagai penghasil benih}

Mula-mula dilakukan oleh kelompok tani di Desa Kuanheun, Kecamatan Kupang Barat, Kabupaten Kupang. Kelompok ini mulai mengembangkan tanaman leguminosa pohon lamtoro Tarramba yang ditanam pada lahan 2 ha, dengan jarak tanam $1 \times 2 \mathrm{~m}$, 
namun pemanfaatannya sebagai pakan berkembang lambat antara lain karena petani menanam pakan cukup jauh dari pemukiman dan ternak masih banyak digembalakan. Petani tidak menempatkan ternak di kebun pakan karena jauh dari pemukiman dan rawan pencurian ternak. Selanjutnya kebun pakan ini hanya dimanfaatkan untuk menghasilkan benih yang dilakukan secara berkelompok. Aktivitas penjualan benih juga tidak berjalan baik karena tanah kebun ini dimiliki oleh satu keluarga petani tetapi penanaman serta perawatan tanaman dilakukan secara berkelompok sehingga timbul konflik. Pemilik ingin agar hasil benih hanya untuk pemilik lahan, namun kelompok berkeinginan dibagi secara merata di dalam kelompok sehingga pemanenan tidak berjalan baik karena saling tunggu. Akhirnya penjualan dan pasokan benih untuk memenuhi permintaan dari berbagai stakeholder dilakukan oleh petani dari Desa Oebola Dalam dan berjalan dengan lancar, karena tiap individu dalam kelompok memiliki lahan dan tanaman sendiri-sendiri, atau gotong royong bergilir. Pasokan benih kemudian juga bertambah luas ke kelompokkelompok pengembangan lain yang kemudian mengadopsinya (Kelompok Tani Setetes Madu, Tunas Baru dan Talekomonit di Desa Camplong 1 Kecamatan Fatuleu, Kabupaten Kupang). Hasil dari penjualan benih dipergunakan untuk berbagai keperluan, membeli sepeda motor, kebutuhan seremonial budaya, membeli ternak sapi, memperbaiki rumah, dan membayar untuk penyambungan listrik PLN.

\section{Sebagai penghasil pakan yang digunakan untuk ternak penggemukan dan/atau breeding}

Pemanfaatan pakan lamtoro Tarramba yang berhasil cukup baik terjadi pada Kelompok Tani Bersaudara di Desa Oebola Dalam yang memulai dengan penggemukan lima ekor ternak sapi pada tahun 2013, hingga mencapai 45 ekor dalam sekali periode penggemukan (enam bulan hingga satu tahun bergantung ukuran dan berat ternak ketika mulai diberikan pakan secara intensif di kandang). Pertambahan jumah ternak yang digemukkan bertambah terus mengikuti pertambahan areal tanam dan jumlah pohon yang terus meningkat setiap tahun. Kelompok tani pengembang, yaitu Setetes Madu selanjutnya mulai melakukan penggemukan ternak dengan cara pemberian pakan berbasis lamtoro Tarramba secara intensif di kandang dengan jumlah ternak yang terus meningkat dari lima ekor hingga saat ini telah mencapai >20an ekor (mulai tahun 2014) untuk penggemukan dan breeding, diikuti pertambahan luas areal tanam (dari 20 ha tahun 2014 hingga $>150$ ha tahun 2017).

\section{Sebagai pakan yang dijual ke pasar hewan atau petani lainnya}

Dengan cara ini seorang petani dapat melakukan antara 6-7 kali panen dari kebunnya selama musim kemarau dan menjual dengan menggunakan angkutan mobil pick up, yang memberikan pendapatan tunai Rp. 350.000-500.000 rupiah sekali pangkas dan jual (harga tahun 2014). Petani yang melakukan ini biasanya tidak memiliki ternak sapi ketika terlibat dengan kegiatan penanaman lamtoro. Hasil dari penjualan ini memungkinkan petani bersangkutan dapat memperoleh uang tunai untuk membeli ternak babi dari ras yang unggul, membeli ternak babi dewasa untuk keperluan urusan seremonial adat setempat, dan membeli kebutuhan keluarga sehari-hari.

Pada pemanfaatannya sebagai pakan penggemukan mampu memberikan pertambahan bobot badan harian $(\mathrm{PBBH})$ ternak sapi Bali di Timor antara 0,5-1 kg/ekor/hari, lebih tinggi dari kondisi petani antara 0,2-0,3 kg/ekor/hari (Nulik \& Kana Hau 2015). Pada penelitian pemberian pakan pada sapi SO, mampu memberikan kenaikan berat badan selama kemarau dibandingkan dengan ternak yang hanya mengandalkan rumput alam di padang penggembalaan yang terus mengalami kehilangan berat badan selama kemarau (Kana Hau \& Nulik 2015). 


\section{Luas dan skala pengembangan}

Informasi yang diperoleh dari kelompok fokus pengkajian (Tabel 1) dan informasi pengembangan dan pemanfaatan yang diperoleh dari individual petani, kelompok tani dan petugas lapangan dari dinas peternakan provinsi dan kabupaten (melalui komunikasi telepon seluler) disajikan dalam Tabel 2.

Tabel 2. Pengembangan dan pemanfaatan pakan ternak leguminosa (pohon dan herba) di NTT, selama beberapa tahun terakhir hingga awal 2017

\begin{tabular}{|c|c|c|}
\hline Jenis/lokasi & Luas penanaman (ha), pemanfaatan, keuntungan & Keterangan \\
\hline \multicolumn{3}{|l|}{ Lamtoro Tarramba } \\
\hline $\begin{array}{l}\text { Kabupaten } \\
\text { Kupang, TTS, } \\
\text { TTU dan Malaka*) }\end{array}$ & $\begin{array}{l}\text { Luasan } 521 \text { ha sebagai sumber pakan dan benih, jumlah } \\
\text { tanaman } 1.065 .677 \text { tanaman. Sedikitnya } 1.091 \text { orang } \\
\text { petani, lebih dari empat ton benih terjual, dengan } \\
\text { pemasukan bagi kelompok tani }>80 \text { juta rupiah tahun } \\
2016 / 2017\end{array}$ & $\begin{array}{l}\text { Pengembangan } \\
\text { sejak tahun } 2014\end{array}$ \\
\hline $\begin{array}{l}\text { Kabupaten } \\
\text { Nagekeo*) }\end{array}$ & $\begin{array}{l}\text { 2-3 ha dikelola } 10 \text { orang petani dan di kebun dinas } \\
\text { peternakan sebagai sumber pakan dan benih untuk } \\
\text { pasokan lokal, pakan sepanjang tahun, tersedia benih } \\
\text { untuk kebutuhan lokal }\end{array}$ & $\begin{array}{l}\text { Pengembangan } \\
\text { sejak tahun } 2012\end{array}$ \\
\hline $\begin{array}{l}\text { Kabupaten Sabu- } \\
\text { Raijua*) }\end{array}$ & $\begin{array}{l}\text { 4-5 ha lamtoro dikelola } 10 \text { petani sebagai sumber pakan, } \\
\text { tersedia pakan sepanjang tahun }\end{array}$ & $\begin{array}{l}\text { Pengembangan } \\
\text { sejak tahun } 2014\end{array}$ \\
\hline $\begin{array}{l}\text { Kabupaten } \\
\text { Rotendao*) }\end{array}$ & 2-3 ha lamtoro sebagai sumber pakan & Sejak tahun 2015 \\
\hline $\begin{array}{l}\text { Kabupaten Sumba } \\
\text { Timur }\end{array}$ & $\begin{array}{l}5 \text { ha lamtoro dikelola kurang lebih } 50 \text { orang petani, } \\
\text { belum optimal dimanfaatkan sebagai pakan atau } \\
\text { penghasil benih. Pada penelitian pemberian pakan } \\
\text { terbukti mampu memberikan PBB positif selama } \\
\text { kemarau, ketika ternak sapi di padang terus kehilangan } \\
\text { berat badan }\end{array}$ & $\begin{array}{l}\text { Introduksi sejak } \\
\text { tahun } 2012 \text {, } \\
\text { berkembang lambat }\end{array}$ \\
\hline \multicolumn{3}{|l|}{ Clitoria ternatea } \\
\hline $\begin{array}{l}\text { Kabupaten Kupang } \\
\text { dan TTS }\end{array}$ & $\begin{array}{l}30 \text { ha dikelola } 60 \text { orang petani, menyuburkan tanah, } \\
\text { sebagai sumber pakan dan penghasil benih. Ditanam } \\
\text { bersama jagung secara rotasi atau relay dan berotasi } \\
\text { dengan tanaman padi. Menekan angka kematian anak } \\
\text { sapi yang lahir di musim kemarau }\end{array}$ & $\begin{array}{l}\text { Dimanfaatkan } \\
\text { sebagai pakan } \\
\text { ternak dan } \\
\text { menghasilkan benih }\end{array}$ \\
\hline $\begin{array}{l}\text { Kabupaten } \\
\text { Nagekeo }\end{array}$ & $\begin{array}{l}\text { 2-3 ha sebagai penghasil benih dan pakan oleh kelompok } \\
\text { tani dan komunitas Gereja }\end{array}$ & $\begin{array}{l}\text { Aktif tahun 2012- } \\
\text { 2014, terhenti dan } \\
\text { aktif lagi tahun } \\
2017\end{array}$ \\
\hline $\begin{array}{l}\text { Kabupaten Sumba } \\
\text { Timur }\end{array}$ & $\begin{array}{l}5 \text { ha leguminosa herba }(C \text {. ternatea) dikelola } \pm 10 \text { orang } \\
\text { petani sebagai pakan suplemen bagi ternak induk selama } \\
\text { kemarau (night feeding untuk sapi gembala). Leguminosa } \\
\text { herba lebih disukai ternak sapi SO. Memperbaiki } \\
\text { performans induk SO sehingga mampu menghasilkan } \\
\text { anak setiap tahun }\end{array}$ & $\begin{array}{l}\text { Leguminosa herba } \\
\text { mempunyai } \\
\text { peluang adopsi } \\
\text { lebih baik } \\
\text { dibandingkan } \\
\text { dengan lamtoro } \\
\text { Tarramba }\end{array}$ \\
\hline
\end{tabular}

*Termasuk Kelompok di luar jangkauan kunjungan yang hanya dijangkau dengan telepon dan SMS untuk mengetahui perkembangan penanaman leguminosa yang diintroduksikan; TTS: Timor Tengah Selatan; TTU: Timor Tengah Utara 


\section{KESIMPULAN}

Perkembangan luasan penanaman dan pemanfaatan tanaman pakan berbasis leguminosa, terutama leguminosa pohon Leucaena leucocephala cv Tarramba ( $>500 \mathrm{ha})$ dan leguminosa herba yaitu Clitoria ternatea ( $>50$ ha) di NTT semakin meningkat dari tahun ke tahun sejak penelitian dan pengkajian tahun 2011 hingga 2017 untuk leguminosa herba, dan sejak 2012 sampai 2017 untuk leguminosa pohon. Perkembangan yang baik ini terutama didukung oleh berbagai faktor pemicu (keunggulan tanaman pakan, kualitas hijauan pakan, pertumbuhan dan performa ternak yang diberi pakan leguminosa dan adanya keuntungan lain seperti energi terbarukan dan pendapatan tambahan yang sebelumnya belum pernah diperoleh dari lahan yang sama selama musim kemarau).

Perkembangan yang terus meluas dan adopsi yang makin meningkat hingga saat ini, antara lain dilihat dari jumlah benih yang dibeli dari kelompok tani untuk distribusi ke berbagai tempat di dalam Provinsi NTT dan juga ke luar. Hal ini makin memberikan harapan terhadap usaha ternak ruminansia terutama ternak sapi yang makin baik dan berkelanjutan di daerah ini.

Perbaikan usaha ternak ini masih perlu ditingkatkan lewat upaya pendampingan dan pelatihan bagi peternak, terutama dalam hal cara pemberian pakan yang baik (berimbang antara protein, serat dan energi), perkandangan, serta pengelolaan dan pemanfaatan kotoran ternak, terutama pada kelompok-kelompok yang belum mendapatkan pendampingan penuh dalam penerapan teknologi.

\section{UCAPAN TERIMA KASIH}

Kedua kegiatan penelitian dan pengkajian Leucaena leucocephala cv Tarramba dan Leguminosa Herba terselenggara oleh dukungan dana hibah dari ACIAR (LPS/2008/054, LPS/2006/003 dan LPS/2012/064) karena itu penulis ucapkan terima kasih. Ucapan terima kasih disampaikan kepada rekan-rekan peneliti dari CSIRO (Mr. Neal Dalgliesh dan Dr. Lindsay Bell), DPIF (Dr. Kendrick Cox), University of Queensland (Dr. HM Shelton dan Mr. Michael Halliday) dan para peneliti lapang ACIAR (Charles Pakereng, Resti Edison, Dhesy Liubana, Putri Ara, Daniel Tatuin, Petrus Manoe, Yendri Abi, Jack Uran, Jeff Praing dan R Rebo).

\section{DAFTAR PUSTAKA}

Abi Y, Nulik J, Hosang EY, Kana Hau D. 2016. Penampilan dan produksi padi dan jagung setelah tanaman leguminosa. Laporan tahunan ACIAR-BPTP NTT. Kupang (Indonesia): BPTP Nusa Tenggara Timur.

Bassa Z. 2016. Determinants of improved forages adoption in Doyogena District of Kembata Tembaro Zone, in Southern Nations, Nationalities Regional State, Ethiopia. Glob J Sci Front Res: D Agric Vet. 16:6-13.

Hosang E, Nulik J, Kana Hau D, Abi Y, Bell L. 2016. Nitrogen contribution from forage legume in maize farming system in West Timor, Indonesia. In: Solutions to Improve Nitrogen for the World. Proceedings of 2016 International Nitrogen Initiative Confernece. Melbourne, 4-8 December 2016. Melbourne (Australia). p. 1-4.

Kana Hau D. 2014. The potency of using and developing local and introduced herbaceous legume forages in East Nusa Tenggara, Indonesia. In: Proceedings of The $16^{\text {th }}$ AAAP Congress. Yogyakarta, 10-14 November 2014. Yogyakarta (Indonesia). p. 2710-2713. 
Kana Hau D, Panjaitan T, Nulik J, Dahlanuddin, van de Fliert E. 2014. Barriers to and opportunities for the use of forage tree legumes in smallholder cattle fattening systems in Eastern Indonesia. Trop Grasslands-Forrajes Trop. 2:79-81.

Kana Hau D, Nulik J. 2015. Body weight gain response of sumba ongole cattle to the improvement of feed quality in East Sumba District, East Nusa Tenggara, Indonesia. In: Integrated Approach in Developing Sustainable Tropical Animal Production. Proceedings of The $6^{\text {th }}$ International Seminar on Tropical Animal Production. Yogyakarta, 20-22 October 2015. Yogyakarta (Indonesia). p. 143-146.

Nulik J, Kana Hau D, Fernandez PT, Ratnawati S. 2004. Adaptasi beberapa Leucaena spesies di Pulau Timor dan Sumba NTT. Dalam: Thalib A, Sendow W, Purwadaria T, Tarmudji, Darmono, Triwulanningsih E, Beriajaya, Natalia L, Nurhayati, Ketaren PP, Priyanto D, Iskandar S, Sani Y, penyunting. Iptek sebagai motor penggerak pembangunan sistem dan usaha agribisnis peternakan. Prosiding Seminar Nasional Teknologi Peternakan dan Veteriner. Bogor, 4-5 Agustus 2004. Bogor (Indonesia): Puslitbangnak. hlm. 825-831.

Nulik J, Bamualim A. 1998. Pakan ruminansia besar di Nusa Tenggara. Balai Pengkajian Teknologi Pertanian Naibonat bekerjasama dengan Eastern Island Veterinary Services Project.

Nulik J, Kana Hau D. 2015. Daily body weight gain of Bali cattle fed with Leucaena leucocephala as the main ration in West Timor, East Nusa Tenggara. In: Integrated Approach in Developing Sustainable Tropical Animal Production. Proceedings of The $6^{\text {th }}$ International Seminar on Tropical Animal Production. Yogyakarta, 20-22 October 2015. Yogyakarta (Indonesia). p. 147-150.

Nulik J, Kana Hau D. 2016. Forage growing and hay making of Clitoria ternatea for dry season feed supplement in East Nusa Tenggara, Indonesia. In: The $17^{\text {th }}$ Asian Australian Association of Animal Production Societies Animal Science Congress Proceedings. Fukuoka, 22-26 August 2016. Fukuoka (Japan).

Nulik J, Dalgliesh N, Cox K, Gabb S. 2013. Mengintegrasikan legum herba ke dalam sistem tanaman dan ternak di Indonesia bagian Timur. Australian Centre for International Agricultural Research (ACIAR).

Wambugu C, Place F, Franzel S. 2011. Research, development and scaling up the adoption of fodder shrub innovations in East Africa. Int J Agric Sustain. 9:100-109.

\section{DISKUSI}

\section{Pertanyaan}

Mana model yang paling tinggi hasilnya dan sudah berapa banyak pengembangannya?

\section{Jawaban}

Yang paling baik dengan sistem monokultur dan sudah disebar, serta dikembangkan sebanyak 70 ha. 